Original Article

\title{
At-home care - interactions between nurses and the elderly/family*
}

\author{
Cuidados domiciliares - interação do enfermeiro com a pessoa idosa/família \\ Cuidados domiciliarios - interacción del enfermero con la persona anciana/familia
}

Esperança Alves Gago ${ }^{1}$, Manuel José Lopes ${ }^{2}$

\begin{abstract}
Objective: To understand the interaction process between the elderly and the family and the nurses during home care. Methods: Grounded theory qualitative study in a community where $40 \%$ of the population is aged 65 or above. The collection of data was made via the non-participating observation of nursing practice during 41 home visits and semi-structured interviews to nurses, the elderly and the family. Results: the following categories emerged - structural organization of at-home care, diagnostic assessment in context and therapeutic intervention in context. Conclusion: the central category was "Building the relationship in an at-home context", due to the fact that the relationship between the nurse, the elderly and the family is central across the entire care process. The relation is, simultaneously, the context for all the care and a therapeutic instrument.
\end{abstract}

Keywords: Nursing care; Home housing; House visit; Health of the elderly

\section{RESUMO}

Objetivo: Compreender o processo de interacção com a pessoa idosa e família no domićlío desenvolvido pelos enfermeiros. Métodos: Estudo de natureza qualitativa, Grounded Theory, em uma comunidade onde 40\% da população têm idade igual ou superior a 65 anos. A coleta dos dados foi pela observação não participante das práticas de enfermagem, durante 41 visitas domiciliárias e entrevistas semiestruturadas às enfermeiras, pessoa idosa e família. Resultados: Emergiram as categorias: organização estrutural dos cuidados domiciliares, avaliação diagnóstica em contexto e intervenção terapêutica em contexto. Conclusão: A categoria central foi "Construindo a relação em contexto domiciliar" pelo fato da relação da enfermeira com o idoso e a família ser central em todo o processo de cuidados. A relação é simultaneamente o contexto de todos os cuidados, assim como é um instrumento terapêutico.

Descritores: Cuidados de enfermagem; Assistência domiciliar; Visita domiciliar; Saúde do idoso

\section{RESUMEN}

Objetivo: Comprender el proceso de interacción de los enfermeros con la persona anciana y la familia en el domicilio. Métodos: Estudio de naturaleza cualitativa, Grounded Theory, realizado en una comunidad donde el $40 \%$ de la población tiene una edad igual o superior a 65 años. Para la recolección de los datos se usó la observación no participante de las prácticas de enfermería, durante 41 visitas domiciliarias y entrevistas semiestructuradas realizadas a las enfermeras, persona anciana y familia. Resultados: Emergieron las categorías: organización estructural de los cuidados domiciliarios, evaluación diagnóstica en el contexto e intervención terapéutica en el contexto. Conclusión: La categoría central fue "Construyendo la relación en el contexto domiciliario", por el hecho de ser la relación de la enfermera con el anciano y la familia el centro en todo el proceso de cuidados. La relación es simultáneamente el contexto de todos los cuidados, así como el instrumento terapéutico.

Descriptores: Cuidados de enfermería; Atención domiciliaria de salud; Visita domiciliaria; Salud del ancianos

\footnotetext{
* Study conducted in four parishes of the municipality of Vila Nova de Famalicão (VNF) - Braga-Portugal.

${ }^{1}$ Master of Science in Nursing (MSN) by ICBAS, University of Porto, Doctoral Student at University of Evora. Coordinator Professor of the College of Nursing (Escola Superior de Enfermagem), University of Minho - Braga - Portugal.

2 Doctor of Science in Nursing by ICBAS, University of Porto, Director of São João de Deus College of Nursing (Escola Superior de Enfermagem de S. João de Deus), University of Evora - Portugal, Director of the Research Centre in Health Sciences and Technologies.
} 


\section{INTRODUCTION}

Senior citizens are the segment of the population that tends to progressively need more care. This finding is related to the fact that aging inexorably leads to some reduction in functionality. The phenomenon of aging populations is happening globally and one expects that by 2025 there are 1.2 billion people aged 60 or above, representing over $20 \%$ of the world population ${ }^{(1)}$.

Portugal is experiencing a quick aging process, a consequence of the occurrence of two phenomena: the increase in life expectancy and the decrease of the fertility rate and, subsequently, birth rates. According to demographic projects, by the year 2050 senior citizens are expected to represent $32 \%$ of the total population ${ }^{(2)}$. This study was conducted in the country's northern region, at the Health Centre of Vila Nova de Famalicão.

Among the different structured strategies for healthcare what is normally refer to as at-home care or homecare. This corresponds to care given to individuals and families in their places of residence and that aim to promote, maintain or recover health, maximizing the level of autonomy or minimizing the effects of the disabilities or the terminal illness ${ }^{(3)}$.

Thus, nurses have a privileged position to achieve their purpose while reducing the number of hospital admissions and the intake of drugs and also respecting the environment of the at-home care, which is considered "[...] as the social and physical space of interactions and interdependencies of human beings $[\ldots]$ ".(4).

During the at-home care, nurses dive into the cultural and living space of each family, which calls for a great adaptability, but also an understanding of the different specificities of each one of these spaces as to earn the trust of the people being taken care of, which will allow them to use all resources to the advantage of the therapeutic project. This situation means that "[...] the daily work requires reflection on the need to adopt innovative behaviors and postures[... $]^{\prime(5)}$.

In this sense, the " $[\ldots]$ the knowledge built and used in the nurses' daily work [...]" ${ }^{\prime()}$ was the motivation behind this study, with the following questions: how do nurses develop this process? Which knowledge of nursing is underlying to this care? How do nurses organize and structure at-home care? Which strategies do they use to be accepted in the intimate and private environment of the people receiving the healthcare? When or how do nurses feel that they are already accepted by the people they are caring for? How do nurses mobilize the different resources - material and human - as to obtain answers to complex situations they encounter? Which therapeutic interventions are developed in such contexts?

The creation of the Rede Nacional de Cuidados Continuados Integrados (National Network of Integrated Long-
Term Care $)^{(7)}$ reflects the political concerns about the need to provide healthcare answers to communities, particularly regarding functionally dependent elderly.

Thus, functional ability becomes " $[. .$.$] a new health$

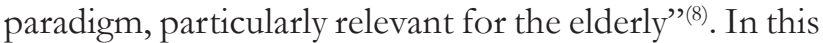
sense, what determines the well-being of the senior citizen is his/her autonomy, i.e., the ability he/she has to manage his/her life socially, leisurely and other areas.

Therefore, the maintenance of autonomy and/or reduction of functional deficit require a multidisciplinary work but that, historically and in our contexts, integrates the work performed by nurses. According to Orem's general theor $y^{(9)}$, nurses are called agents of therapeutic self-care when the people on their own have no ability to develop self-care. These health workers are the key elements in individual, family and community guidance, in important health-related decisions, with competencies in implementing health-promotion intervention, in diagnosing restraining factors due to the family's socioeconomic origin and in guiding the elderly and his/her family towards the competent institutions ${ }^{(10)}$.

The home acts as a health unit, outside the walls of formal health institutions, the comfort, the space and the material and human resources. At the patient's home, nurses have to deal with several contingencies, namely the fact that they do not belong in the context in which the care will take place. $\mathrm{He} /$ she is someone from the outside in a private space. It also needs to adequate therapeutic interventions, understood as a " $[. .$. set of specific nursing interventions and with proven therapeutic potentialities."(11)

The adequacy of the interventions results from the promotion of the participation of the elderly/family in the at-home care. The promotion of this participation may be seen in the light of the assumption, mentioned by $\operatorname{Orem}(9)$ that self-care is not innate, but rather a behavior that is learned and experienced.

Regarding the objective of at-home care, Rice ${ }^{(12)}$ identified giving the elderly and the family the understanding, the support, the treatment, the information and the care they need to successfully manage their health needs at home. There are gaps between the development of the knowledge on health promotion and the prevention of illnesses and their practical application.

In the scientific literature, no studies were found with the purpose of conceptualizing the interaction process between nurses and the elderly and the family in the healthcare provided at home.

In light of the foregoing, several questions come forward; however, this research was developed based on the following question: How is the nursing care process to the elderly/family developed at home?

Thus, the objectives of this study were: 
1 - To understand how nurses organize and structure home visits.

2 - To identify the strategies developed by nurses so that they are accepted in the intimate and private environment of the people receiving the healthcare.

3 - To understand the attitudes observed/felt by nurses during their interaction with the elderly/family and that indicated that they were already accepted by the people they are caring for.

4 - To identify how nurses mobilize the different resources - material and human - to obtain answers to complex situations they encounter.

5 - To identify the therapeutic interventions that are developed by nurses in at-home contexts.

\section{METHODS}

Qualitative inquiry-based approach research, based on the Grounded Theory method ${ }^{(13)}$, which is adapted to the creation of a theory inductively derived from data. This means that the theory is built and developed provisionally and verified by the systematic collection of data and their constant analysis. The reason behind this option is justified by the absence of theories on the interaction process between nurses and the elderly and family at home.

The study was carried out in four parishes of the city of Vila Nova de Famalicão (VNF)- Portugal, belonging to the same Health Care Center. Of the 136458 users inscribed at the health center, $58.8 \%$ belonged to the communities being studied. Of the latter, $12.7 \%$ was aged 65 or above.

Concomitantly with the selected method, one opted for the theoretical sampling and the data collection was stopped when one verified that no new data was being added.

In this study, the reporters were the nurses of the Health Care Centre (HCC) of Vila Nova de Famalicão, who had been rendering, exclusively, at-home health cares for at least one consecutive year within the same geographical context, as well as the elderly and the families receiving the at-home care. Six nurses and seven senior citizens and respective families took part on the study, which were indicated by the nurses. Data collection was performed through the non-participative observation during 41 home visits to senior citizens, for a consecutive period of 2 months, accompanying the nurses of the HCC.

The observation had the following objectives: to understand how the home visit was prepared; to understand the different unforeseen situations the nurse was confronted with and how they were solved; to identify the competences mobilized by the nurses during the care process; to structure the semi-structured interview guide.
This observation resulted in the record of field notes, outlined during the trips between the users' homes, by means of a detailed description of each topic at the end of each visit.

One also conducted 12 semi-structured interviews with the six nurses and 7 with the elderly and families, which occurred in a 6-month time interval. The interviews with the elderly and families were done at their homes. Nurses were interviewed in a private room at the Health Centre. All interviews' audio was recorded and later transcribed. The question done during the interview was to request the nurses to "describe their practices" but other questions were also made, so that the researcher could clarify some aspects that were not completely explicit. The interview with the elderly and families was based on the perception these had regarding the at-home nursing care.

Considering ethical aspects, the entire process was conducted according to ethical principles, such as confidentiality, anonymity and Informed Consent, signed by the participants in the study, as well as the written authorization of the Health Center's Director.

Data were analyzed using the constant comparative analysis method. Analysis techniques and tools included procedures of open, axial and selective coding. During the open coding, between the different possibilities, one opted for the microanalysis, which consisted in the coding of all text, word for word or line for line. Axial coding allowed the grouping and relation of the previously identified concepts. During the selecting coding, the refinement of the process allowed the identification of the central category, which is related to all categories and subcategories.

The support tool being used throughout the data analysis was the NVivo8 ${ }^{\circledR}$ Software.

\section{RESULTS}

In this process, the interaction developed between the nurses and the elderly/family was particularly relevant. For that reason, the central category of this substantive theory was called "building the relationship in an at-home context".

A theory is more than the group of results, it should explain the phenomenon that is to be understood ${ }^{(13)}$. Thus, in such a theory (i.e., a substantive theory), understanding the phenomenon requires knowledge of the context. This will help one to understand the web of relationships the various categories have with each other and between them and the central category.

Considering the senior citizens observed in this study, 18 were males and 23 were female, with an average age of 78 years. The qualifications of the elderly males were mostly the first cycle of basic education, 
while the majority of elderly women had no schooling. The marital status of widowhood characterized the most elderly females, while males tended to be married. Women were all retired and all showed changes in functionality primarily due to changes in the structure and/or bodily functions ${ }^{(14)}$.

These persons were supported by family members, including nieces, wives and daughters. One also observed a good relationship between neighbors, specifically in collaborating with the caregivers and with the elderly in small tasks.

The formal social network, which included Private Social Solidarity Institutions and Catholic Organizations, would help whenever such was requested, regarding hygiene, supply of food and laundry service. In their vast majority, houses were located in a rural environment, had basic sanitation, electricity, water and also a small backyard. These residences also had small access barriers as, for instance, stairs or irregular floors.

The distance mediating the homes visited and the $\mathrm{HC}$ varied greatly, with a maximum distance of $6 \mathrm{ki}-$ lometers; however, the average number of nurse-programmed visits for a period of approximately 4 hours was 16.

The age average of the informant nurses was 35; four had graduated in Nursing and two were post-graduate in Community Health. On average, they have been rendering at-home care for nine years and were professional nurses for 13 .

The relationship between the nurse and the elderly and family assumed a central role in the entire care process, reason why it became the central category. The relationship is both the context of all healthcare and also a therapeutic tool. It was assumed as a continuous and progressive process, which starts when the senior citizen is referred as being in need of nursing care and is extended over time, even after the initial problem that caused the reference is solved.

The uncertainty of the time duration of the relationship with the elderly person is motivated by the fact that the aging process is characterized by physiological changes that will require progressive adaptations regarding self-care. Nurses maintain the home visits, albeit with a lower frequency, developing a supportive and preventive role.

Within the relationship that is developed, nurses find the necessary environment to obtain the data they need to understand the care needs of the elderly. Thus, as time goes by, the nurses' answer goes beyond the initial (healing) objective and begins including other dimensions, using different intervention strategies and with other therapeutic objectives.

Therefore, this progressivity of the relationship and, as a consequence, of the care process depends on the acceptance and the trust bonds developed between nurses and the people being cared for. This situation is perceived by nurses via signs that included being informed where to find the key to open the front door, being invited to enter other rooms of the house that are not the room where the care process takes places, and also because the house doesn't look so "tidy", as if the nurse was an outsider, because they shares good and bad situation that happen in the family environment.

The trust and acceptance of the presence of the nurses allows the emergence of a change in attitudes that promote the well-being of people cared.

The solidity of the central category "Building the relationship in an at-home context" is obtained by the relationship and connection with their satellite categories: "Structural organization of home care", "Assessment in Context" and "Intervention in Context", which are also related and interrelated between themselves.

In the following image (Image 1), one schematically presents the dynamic of the interrelation and articulation between the central category and the satellite categories and, concomitantly, the interrelationships and articulations between the latter.

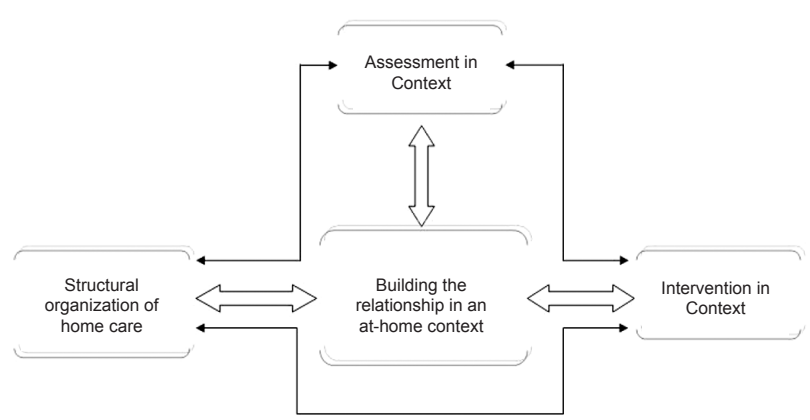

Image 1. Relationship and articulation of the central category with the satellite categories

The construction process of the relationship is not developed via linear and hierarchical sequential steps, but rather via a flexible professional attitude that is managed by a work plan that depends on the fact that it is a first visit or follow-up visit, during which the nurses build and rebuild the assessment and adapt interventions to the health-illness situations they witness, as well as the availability and openness they feel on the person receiving the care.

Even though, each of these "steps" (categories) has its own characteristics, which are explained hereinafter, although due to the limited space, it was only possible to discuss the category "Structural organization of home care." 


\section{Structural Organization of Home Care}

The structural organization of home care consists of the activities carried out by the nurse, still within the Health Centre, as to prepare the care process to a group of people throughout the day dedicated to home visits. For that purpose, the nurse begins by gathering the necessary information, using diverse sources of information, such as: personal records and global knowledge of the people she/he takes care of, hospital discharge documents, requests from users and requests from the family physician. The variety of sources results from the diversity of situations with which she/he anticipates, but also from whether it is the first visit or follow-up visits. Depending on the information collected, which in practice become the elements necessary for the first diagnostic evaluation, the nurse plans her/his work day. This demonstrates the interrelationship between this category and the assessment in context. In fact, this anticipatory assessment may be modified by the data collected in context.

Apart from the abovementioned information sources and with the objective of planning the work day, the nurse equates other variables, including the recipient of the nursing care, clinical supplies and geographical distance.

Image 2 schematically represents the diversity of factors taken into account during this stage of the care process, as well as the complexity of relations between them.

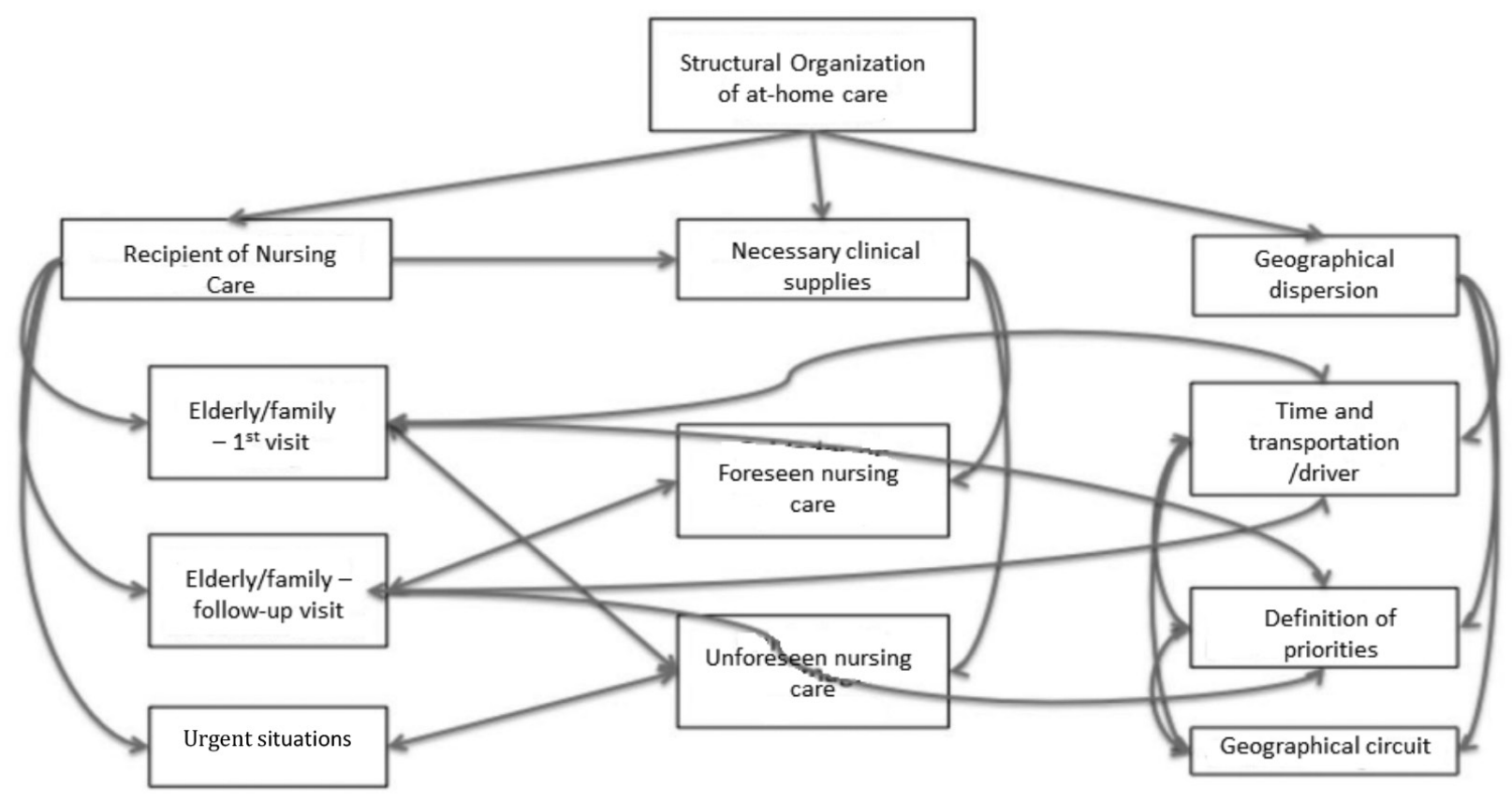

Image 2. Scheme for the Structural Organization of Home Care

When organizing the care, nurses face some fundamental caveats, such as the recipient of the nursing care, geographical distance and clinical supplies. The latter are decided according to the foreseen nursing care and also from the nurses' experience in anticipating unforeseeable events.

The recipient of the nursing care determines the care to develop at home, as well as the definition of priorities. These, in turn, allow making a decision on the geographical circuit to travel and also the clinical supplies to be selected for the home visit. The nurses are faced by three possibilities as far as the recipient of the nursing care goes: the elderly/family that still hadn't receive any at-home care, which were designated for a first visit; the elderly/family that has already been visited and that needed follow-up care; and, finally, the elderly/family that had follow-up visit but, due to an unforeseeable event, called for a visit outside the period the nurse had scheduled.

Elderly/family - first visit: the referral of that person may have been done via a discharge document sent by a hospital, meaning that it results from a hospital stay of the elderly and subsequent discharge, with the need for long-term care, or from the indication of the 
family physician or even from the direct request of a family member. Usually, the information obtained is related to the clinical diagnostic and healing care needs.

Elderly/family - follow-up visits: in this case, there is a cumulative knowledge that results from the previous visits, which allows the understanding of the health/illness situation, but also of the social and family context. This knowledge allows the planning of care that responds to the first primary request, but it concurrently responds to other needs that have been detected since. The nurses' interventions now include, beyond the strictly healing dimensions, health-related guidance, prevention, promotion and surveillance.

Urgent situations: This situation occurs when there are complications of any given nature during the time between visits, not being, therefore, foreseen. As an example, the absence of urine on the collector, a catheter coming out or something abnormal, which is felt or observed by the elderly and/or family and that calls for the nurse's direct intervention. These cases are usually signaled by phone, a contact that the nurse provides in the first visit.

Clinical supplies needed regard the set of surgical instruments, bandages, adhesives, solutes, therapeutic dressing materials, puncture material, and catheterization material, among others. The decision to select these supplies depends on the knowledge the nurse has over the different health/illness situations seen during the visit, while also anticipating that there could be unforeseeable events that may happen during this complex process, which are designated by "anticipated nursing care" and "unforeseeable nursing care".

The geographical distance is another problem that nurses need to consider in order to maximize the time set by the directors of the HC, as well as the availability of car and its driver. After this analysis, they develop their plan by establishing priorities in health needs and, subsequently, with their knowledge of the geographical area and, with the opinion by the driver, the circuit to be made is defined.

\section{DISCUSSION}

In this methodological approach, the discussion was carried out by comparing the concepts discovered with similar concepts found in other studies. Thus, based on the two concepts mentioned, one underlines some of the characteristics of the central concept "Building the relationship in an at-home context". Therefore, the relationship begins before the 1 st encounter and is prolonged beyond the duration needed for the treatment, acts as a care context, hence facilitating the systematic assessment. As care in itself, the construction process of the relation is progressive, largely depending on the evaluation of trust and, finally, it is a flexible process.
These characteristics are present in some of the studies most recently developed in Portugal, although in different contexts. Hence, in the study by Lopes ${ }^{(11)}$ and also in Sapeta's ${ }^{(15)}$, Frias ${ }^{\text {(16) }}$ and Oliveira's ${ }^{(17)}$, one finds the anticipatory dimensions, meaning that, in fact, the nurse collect information via the most diverse shapes and sources about the people she/he will care, thus initiating her/his relationship with them.

These studies have highlighted the double dimension of the relationship, context of the care and care in itself. Notwithstanding, one should emphasize that, against the abovementioned studies, this study was developed in at-home context. Thus, despite the similarities, it acquires particularities worth highlighting, because the nurse acts as an anthropologist, i.e., she/he needs to know the specificities of each family with whom she/ he will contact and adapt her/his intervention to them.

The progressivity and flexibility of the construction process of the relation are also common to many studies, such as those of Peplau ${ }^{(18)}$, Orlando ${ }^{(19)}$ and Exley and Allen ${ }^{(20)}$.

Regarding the concept "Structural Organization of home care", one highlights, on the one hand, the multifocality and, on the other, the clinical decision. As for the first and similarly the study by Lopes ${ }^{(11)}$, one may state that the primary attention focus of nurses is the person for whom the care was requested, but it is also true that, according to the different circumstances, nurses may be focused on the interface elderly-family, on the different organizations interacting with the family, including other professionals, other community realities and other contingencies related to the management of clinical supplies and geographical circuit, along with time constraints, the means of transportation and the driver. Therefore, this concept is highlighted by acquiring unique characteristics, marked by the community context of care.

Although the clinical decision is mentioned, in this concept, as the one being the most relevant, but it is transversal to all others. The characteristics of the clinical decision as they are become quite near to the model proposed by Jesus ${ }^{(21)}$, although the latter was developed in a hospital context. Like so, similarly to the abovementioned model, one might state that here one always finds the presence of " [...] two permanent continuous elements, to interact and to intervene, which, in turn, enable three other continuous elements: to know the patient, to solve problems and to assess" ${ }^{(19)}$. Also in the study of Lopes ${ }^{(11)}$ and in the one of Sapeta ${ }^{(15)}$ the interweaving between interacting and intervening is present.

The methodological options of this study are closely related to the absence of a theory on the interaction process between nurses and the elderly/family in an at-home context. Thus, the central category emerged, which was called "Building the relationship in an at- 
home context", since the relationship between nurse and the elderly/family is central to the entire caring process. The relation is, simultaneously, the context for all the care and a therapeutic instrument.

In this sense, the solidity of the central category "Building the relationship in an at-home context" is obtained by the relationship and connection with their satellite categories: "Structural organization of home care", "Assessment in Context" and "Intervention in Context", which are also related and interrelated between themselves.

It is worth highlighting that the concepts "Assessment in Context" and "Intervention in Context", which emerged during the data analysis, must be explained in a later article that will be submitted to publication, with the objective of understanding the phenomenon being studied based on the theory grounded on the data that emerged during this study. As a limitation and to this inductive study, the principle of transferability cannot be applied, since the study was conducted in a predominantly rural environment and only encompassed four parishes in northern Portugal.

\section{REFERENCES}

1. The World Health Organization. The World Health Report 2001. Mental health: new understanding, new hope. Geneva: WHO; 2001.

2. Portugal. Ministério da Saúde. Direcção-Geral da Saúde. Plano Nacional de Saúde 2004-2010: mais saúde para todos. Lisboa: Ministério da Saúde; 2004.

3. Stanhope M, Lancaster J. Enfermagem comunitária: promoção da saúde de grupos, famílias e indivíduos. Lisboa: Lusociência; 1999.

4. Silva RF, Erdmann AL. [The environment for care: ecological dimension].Texto \& Contexto Enferm. 2002; 11 (3):72-82. Portuguese.

5. Pradebon VM, Erdmann AL, Leite JL, Lima SB, Prochnow AG. Complexity theory in the daily experience of the nurse manager. Acta Paul Enferm. 2011 ;24 (1):13-22.

6. Basto ML. Da (in)visibilidade do trabalho das enfermeiras à produção de saberes em enfermagem: cuidados prestados num centro de saúde. Rev Port Saúde Pública. 2005; 23(1):25-41.

7. Portugal. Ministério da Saúde. Decreto-Lei n. 101 de 6 de Junho de 2006. Cria a Rede Nacional de Cuidados Continuados Integrados [Internet]. Diário da República, http://www.rncci. min-saude.pt/SiteCollectionDocuments/38563865.pdf

8. Ramos IR. A mudança de paradigma na saúde e o conceito de capacidade funcional. Guia de Geriatria e Gerontologia. São Paulo: Manole; 2005.

9. Orem D. Nursing: concepts of practice. New York: MacGraw-Hill; 1985.

10. Pender NJ, Murdaugh CL, Parsons MA. Health promotion in nursing practice. 5th ed. New Jersey: Pearson Education; 2006.

11. Lopes MJ. A relação enfermeiro - doente como intervenção

\section{CONCLUSIONS}

1 - The organization and structuring of the home visits is begun at the Health Centre, where the nurse needs to equate care priorities regarding the persons being cared for, time available, the geographical route to be chosen and the clinical supplies.

2 - One identified that the strategies the nurses use to be accepted onto the home environment are related to the adequacy of the interventions and the acceptance of their presence in the intimate space of each senior citizen.

3 - Attitudes developed are essentially the promotion of the participation of the elderly/family in the practice of home care.

4 - Nurses mobilize different resources through the knowledge they acquire on the community context and the individual context of each person receiving the care.

5 - Interventions are essentially focused on the interaction to continuously build the relationship in an at-home context.

terapêutica. Coimbra: Formasau; 2006.

12. Rice R. Prática de enfermagem nos cuidados domiciliários: conceitos e aplicação. Loures: Lusociência; 2004.

13. Strauss A., Corbin J Pesquisa qualitativa - técnicas e procedimentos para o desenvolvimento da teoria fundamentada. 2a ed. Porto Alegre: Artmed; 2008.

14. Direcção-Geral da Saúde - Classificação Internacional de Funcionalidade, Incapacidade e Saúde. Lisboa (2004). Tradução de: Organização Mundial da Saúde (resolução WHA54.21)

15. Sapeta P. Cuidar em fim de vida: o processo de interacção enfermeiro-doente. Loures: Lusociência; 2011.

16. Frias CF. O processo de construção de cuidados enfermeiro/ pessoa em fim de vida: encontro de corpos [tese]. Lisboa: Universidade de Lisboa, Escola Superior de Enfermagem de Lisboa; 2010.

17. Oliveira C. O cuidado confortador da pessoa idosa hospitalizada: Individualizar a intervenção conciliando tensões [tese]. Lisboa: Universidade de Lisboa, Escola Superior de Enfermagem de Lisboa; 2011.

18. Peplau H. Relaciones interpersonales en enfermería. Barcelona: Salvat; 1990.

19. Orlando I. Teoria del processo de enfermeria. In: Tomey A, Alligood M. Modelos y teorías en enfermería. 4a ed. Madri: Harcourt Brace; 1999. p. 551-63.

20. Exley C.; Allen D. - A critical examination of home care: End of life care as na illustrative case. Soc Sci Med. 2007;65(11):2317-27.

21. Jesus E. Decisão clínica de enfermagem. Coimbra: Formasau; 2006. 